\title{
Research on Corporate Social Responsibility in Ghana
}

\author{
Mavis Amo-Mensah \\ Department of Communication and Media Studies, University of Education, Winneba, Ghana
}

\begin{abstract}
This study examines the current state of Corporate Social Responsibility (CSR) research in Ghana. The evidence is based on a review of 47 published academic papers retrieved from three key online databases (EBSCOhost, Emerald Insights and Business Source Complete) and content analysis procedures drawn from the extant literature. The analysis demonstrates that the concept of CSR in Ghana is under-theorised. Researchers have focused more on empirical dimensions of CSR, following mostly quantitative methods of research. In addition, majority of the studies were skewed towards large multinational or internationally connected companies, especially those in the mining, banking and telecommunications sectors. This study contributes significantly to research in CSR literature. The study is the first attempt to map the research terrain of the body of knowledge on CSR in Ghana. It provides insights into research studies that have been conducted on CSR in Ghana, the areas that have not been explored, and avenues that exist for further research considerations.
\end{abstract}

Keywords: Corporate Social Responsibility, CSR communication, CSR research, CSR theory, content analysis, Ghana.

DOI: $10.7176 / \mathrm{EJBM} / 11-5-07$

\section{Introduction}

Corporate Social Responsibility (CSR) has received a lot of attention in both academia and practice. The literature, for instance, suggests that the growing demand for responsible business actions stems from the numerous unethical corporate behaviours in the past (e.g. Enron) and in recent years (e.g. Volkswagen) (Amo-Mensah \& Tench, 2018). Today, different stakeholder groups (e.g. consumers, employees, communities, investors) have become much more assertive to keep companies accountable towards positive social and environmental change (e.g. Cone Communications, 2015). With these developments, organisations have also come to realise that focusing on the Triple Bottom Line (People, Planet, Profit) concept is the surest way to build a reputation as a responsible business, which can, in turn, lead to long-term business success and sustainable development (Elkington, 1994). In Ghana, for example, Ofori and Hinson (2007, p.180) argued that "the increasing concern expressed by policy makers about corporate social responsibility and the pressure exerted on firms to demonstrate high ethical standards" have pushed many companies to focus on CSR. This demonstration of ethical standards, highly advocated in the Ghanaian context, is also strongly emphasised in Carroll's (1999) most popular four-part definition of CSR "the economic, legal, ethical and discretionary expectations that a society has of organizations at a given point in time" (p. 283).

In terms of research, the growth of CSR has been bolstered by studies examining various practical and theoretical aspects (Nielsen \& Thomsen, 2012). A review of the literature clearly shows that many scholars have attempted to look at the field of CSR research. De Baker, Groenewegen and den Hond (2005), for instance, adopted bibliometric methods to assess developments in the CSR field over a thirty-year period, specifically looking at citation patterns, epistemological orientations, among other strands. Lockett, Moon and Visser (2006) adopted a desk-based research method to evaluate the state of published CSR research from 1992 to 2002. The study revealed that articles focusing on environmental (36\%) and ethical (31\%) issues dominated CSR research within the period, followed by stakeholder (18\%) and social (15\%) issues. It also emerged that empirical papers (which were also largely quantitative) were more (representing 53\%) than theoretical ones (47\%). From a corporate communication perspective, Nielsen and Thomsen (2012) evaluated the research streams and themes of 54 articles in the CSR management and marketing communication literature between 2000 and 2011. Golob et. al (2013) similarly reviewed 90 published academic papers on CSR communication thorough qualitative content analysis procedures. On their part, Verk and Golob (2013) presented the state of CSR communication research particularly focusing on thematic areas and epistemological streams. The authors found that majority of the papers on CSR communication $(86.7 \%)$ were theoretical in nature contrary to the finding by Lockett et. al. (2006). In another comprehensive review of the CSR communication literature that draws on thematically driven content analysis, Crane and Glozer (2016) looked at theoretical approaches and research dimensions in 124 papers and 10 books. The authors proposed a typology conceptualised as the 4Is (Integration, Interpretation, Identity and Image) of CSR communication based on the research areas identified in the literature.

One notable review of CSR studies within emerging economies is by Belal and Momin (2009). Belal and Momin (2009) conducted a comprehensive analysis of CSR communication studies in emerging economies between 1983 and 2008. The authors found that for the 25- year period, most of the studies on CSR were predominantly descriptive and quantitative, consistent with the finding by Lockett et. al. (2006). Perhaps the 
authors' focus on only English Language accounting journals, which are more likely to rely on statistical methodologies may have accounted for their finding. Significantly, the studies highlighted above provide an understanding of CSR research in the literature in general; however, they do not offer clear insights into what pertains in specific country contexts, or countries within emerging economies or Africa. In other words, extant reviews of the CSR literature have predominantly concentrated on general reviews (e.g. Crane \& Glozer, 2016; Golob et. al., 2013); those that focus on specific countries have not been given much scholarly attention.

In the African region, Visser (2006) observes that the literature on CSR is dominated by studies from South Africa. In his analysis of the CSR literature in Africa between 1995 and 2005, Visser (2006) found that 57\% of the research studies concentrated on South Africa with the remaining 43\% focusing on other countries within the African region. Visser (2008) also noted that research into CSR in Africa is still at an embryonic state which calls for urgent need for further research at the "international, regional, national and sectorial levels as well as on theoretical constructs" (p. 493). In Ghana, some research on CSR have been conducted (e.g. Amo-Mensah \& Tench, 2015; Ansong, 2017; Boateng, 2016). Nevertheless, the highly disintegrated nature of the literature makes it practically challenging to judge the impact of research scholarship in Ghana (Crane \& Glozer, 2016). Till date, no research has attempted to search for and bring together all the studies conducted on CSR in Ghana under one umbrella. The question then is: What is the state of CSR research in Ghana?

This current study, therefore, attempts to fill in this void by identifying and synthesising the research terrain of the body of knowledge on CSR in Ghana. Presenting the state of the fragmented field of CSR in Ghana provides a useful base to identify potential research gaps and areas that need further exploration. The rest of the paper has been organised into four main sections. The following section presents a review of related literature particularly focusing on the published articles on CSR retrieved in the Ghanaian context. The next section discusses the research methodology followed in evaluating the various papers retrieved in the literature. The results of the study are presented afterwards, after which the study concludes by highlighting future research considerations.

The next section provides an overview of the forty-seven articles selected within the CSR literature in the Ghanaian context.

\section{Corporate Social Responsibility Research in Ghana Mining Sector}

From the mining sector, Puplampu and Dashwood (2011) examined the extent to which organisational attributes and antecedents serve as predictors of CSR. Similarly, Andrews (2016) examined the intuitional frameworks that impact on CSR practices and policies of mining companies in Ghana. The paper argued that lack of explicit laws and regulations on CSR in Ghana allows companies to perpetuate their own selfish social and environmental issues. In the same vein, Boso, Afrane and Inkoom (2017) examined the motivations behind CSR in three large Ghanaian mining companies. Amponsah-Tawiah and Mensah (2015) also sought to gain insights into how different stakeholders within the mining sector understand CSR, and further explain how employee health and safety issues have been integrated into the mainstream CSR initiatives of these mining companies. In another study of the mining sector, Mares (2012) looked at Newmont's CSR operations, using literature search, extensive documentary reviews and interviews. On his part, Yankson (2010) assessed mining companies' application of CSR practices focusing on Alternative livelihood Programmes (ALPs) and their impact on local communities. The study found that ALPs implemented as part of Mining companies' CSR contribute to socio-economic development of mining communities. On the other hand, Hilson (2007) found that in spite of the acknowledgements from the industry terrain, mining communities are benefiting little from CSR actions of companies. Within this context, a study by Andrews (2013) argued that a grassroots-oriented approach to CSR will enable extractive companies to successfully deliver on their CSR mandate in ways that inure to the benefit of communities.

\section{Banking Sector}

In the banking sector, a quantitative survey conducted by Hinson et. al. (2016) examined customer preferences and reactions to CSR activities using data from a sample of 384 bank customers in Ghana. The evidence obtained suggests that philanthropic CSR issues lead to positive customer reactions towards banks. In tandem with the findings by Hinson, Renner and van Zyl (2016), Alomenu, Effah and Kutu-Adu (2015) also found that CSR practices of Ghanaian banks were mostly philanthropic and altruistic. The authors also established a positive relationship between CSR and customers' selection of and long-term relationship with banks. On CSR information needs of customers of Microfinance Institutions (MFI) in Ghana, Okoe and Boateng (2016) however found that such needs were primarily ethical and economic than legal and philanthropic, contrary to the findings by Hinson et. al. (2016) and Alomenu et. al. (2015). One other study by Ofori, Nyuur and Darko (2014) relied on responses from 133 questionnaires composed in a Likert scale format. Findings were that, the key drivers for CSR in the Ghanaian Banking sector are legitimacy, profitability and sustainability. The study also found a positive but nonsignificant correlation between CSR and financial performance. Factors such as growth and origin significantly influenced companies' financial performance than CSR. 


\section{Telecommunications sector}

With regard to the telecommunications sector, Hinson and Kodua (2012) examined how MTN, a leading provider of telecommunications service in Ghana, incorporates CSR into its marketing strategy. Mahmoud and Hinson (2012) investigated the combined effect of market orientation, innovation and corporate performance using a convenient sample of marketing managers and executives in the six telecommunications companies in Ghana. The findings of the study suggest that market orientation, innovation and CSR positively influence the business performance of telecommunications companies in Ghana, with innovation being the highest predictor of successful outcomes. In a cross-sectional survey, Anim and Agbemabiese (2015) also discuss how CSR influences consumer purchase decisions using MTN as a case study. The authors find that factors such as brand name, service quality and promotions are more likely to influence consumer purchase intentions than CSR.

\section{Multi-sectors}

On the other hand, Ofori and Hinson (2007) addressed the issue of whether local Ghanaian firms (SMEs) and internationally connected firms operating in Ghana adhere to CSR practices. Drawing on companies listed on the GC100 for the 2003/2004 listing years, Ofori and Hinson (2007) found that internationally connected firms seemed to have a better approach to CSR than their local counterparts. A survey by Lichtenstein et. al. (2013) explored the nature of CSR in the Ghanaian construction industry looking at the project typologies aligned to such activities. Findings revealed three main CSR projects of the construction firms: social, infrastructural and environmental, albeit the industry was more inclined towards social/intangible CSR projects. Nyuur, Ofori and Debrah (2015) examined the impact of Foreign Direct Investment (FDI) inflow on local companies' engagement in CSR in hostcountry institutions, and found a positive correlation between the two. Various forms of CSR knowledge and practices transferred from foreign to domestic firms contributed in part to this relationship. On their part, Simpson, Aboagye-Otchere and Lovi (2016) looked at how internal auditors can contribute to the assurance or integrity of CSR-related disclosures. The data gathered revealed that assurance from the internal audit function can help improve the credibility of companies' CSR reporting. The authors recommended the need to build the capacity of internal auditors to legitimise their role as independent assurance providers for CSR. Kuada and Hinson (2012) empirically compared the CSR drivers and outcomes of randomly sampled foreign (26) and local companies (54) listed on the GC100. While the foreign companies rationalise CSR decisions based on instrumental and legally prescribed principles, the triggers of CSR for the local companies were more discretionary and socially-oriented. This finding is consistent with a study by Owusu-Ansah (2013) which came to similar conclusion that the nature of CSR policies of five conveniently sampled companies in Ghana was mostly socially-oriented and communitybased.

A comparative qualitative analysis by Dartey-Baah, Amponsah-Tawiah and Agbeibor (2015) examined the extent to which companies' CSR practices contribute to Ghana's national development, relying on secondary data from 20 companies in six industry sectors. According to the study, the companies predominantly aligned their CSR to the Millennium Development Goals (replaced by the Sustainable Development Goals in 2016), specifically focusing on issues such as health, education and community development initiatives. Conversely, a quantitative survey by Abugre (2014) found that managements' commitment in organisational CSR positively affects the implementation of responsibility policies and practices. Insights from the study suggest that CSR challenges mostly stem from lack of management's commitment to CSR initiatives particularly in allocating resources to such activities. On the other hand, Nyuur, Ofori and Debrah (2014) draw on data from a research conducted by Gesellschaft für Technische Zusammenarbeit (GTZ) in 2009 to empirically explore the main factors that promote or hinder the development and implementation of CSR in six Sub-Saharan African countries, including Ghana.

\section{CSR and financial Performance/Brands}

Other studies have also established a positive relationship between CSR and financial performance. Famiyeh (2017) concentrated on large and medium-sized companies drawn from the Association of Ghana Industries, Marfo et. al. (2015) centered on companies listed on the Ghana Stock Exchange, while Agyemang and Ansong (2016) and Ansong (2017) looked at randomly selected SMEs. Julian and Ofori-Dankwa (2011) provided another dimension of CSR and financial accomplishment in the Ghanaian context. Their study used slack resources theory to assess the relationship between financial resource availability and CSR, drawing data from 41 firms listed on the Ghana Club 100 (GC100). The authors found a negative relationship between financial resource availability and social engagement. They argued that cross cultural institutional differences lead to different CSR relationships in different cultural or institutional contexts. Thus, weak institutional systems lead to negative CSR responses. Ayogyam et. al. (2014) focused on the impact of CSR on corporate brands. Questionnaires were self-administered to 200 randomly sampled employees from 10 organisations. It emerged that companies' investment in CSR can contribute to brand awareness, brand differentiation and brand equity in line with the finding by Anim and Agbemabiese (2015). The implication is that, organisations that aim to derive long-term value ought to tie their 
CSR activities to their brands.

\section{CSR communication}

Some studies have also analysed companies' online CSR reporting practices. Amo-Mensah and Tench (2015) examined the extent and type of CSR activities top 100 companies in Ghana (GC100) communicate on their websites. Drawing on content analysis procedures, the authors found a significantly low amount of CSR issues on the companies' websites. Information on CSR was also largely limited to philanthropy consistent with the findings by Hinson et. al. (2016) and Alomenu et. al. (2015). In other related studies, Hinson (2011) assessed how four Ghanaian banks (two CSR-award winning versus two CSR non-award-winning banks) engage in online CSR reportage. Hinson, Boateng and Madichie (2010) similarly focused on Banks' disclosure of CSR information via their corporate websites. Opoku Appiah, Asare Amankwah and Adu Asamoah (2016) draw on the stakeholder concept to understand the influence of firm-specific characteristics in companies' online CSR disclosure. Boateng (2016) analysed the websites of banks operating in Ghana to establish the differences that exist between local and foreign banks in CSR communication, while Boateng and Abdul-Hamid (2017) showed that telecommunications companies in Ghana adopt impression management techniques such as boasting and self-promotion tactics in their online CSR communication. Also, in a longitudinal study that assessed companies' annual reports over a ten year period, Welbeck (2017) draws on the Global Reporting Index to measure the extent of social and environmental disclosures of 17 companies listed on the Ghana stock exchange. According to Welbeck (2017) the extent of CSR disclosure of the listed companies was higher over the ten year period, in line with the finding by Capriotti and Moreno (2007) in the Spanish context but contrary to the observation by Amo-Mensah and Tench (2015) in the Ghanaian context. Environmental disclosures were also more than social disclosures during the duration of the study. This particular finding departs from the many researches in Africa (e.g. Amaeshi et. al., 2006) and in Ghana (e.g. Ofori, 2010) that have shown that CSR dimensions are predominantly socially-related. Moreover, Abugre and Nyuur (2015) looked at the extent to which randomly selected public and private organisations in Ghana practice and communicate CSR. Findings from the data showed that $90 \%$ of the companies shows commitment to CSR and use various media to communicate such practices. In Europe, Borglund, De Geer and Hallvarsson (2008) came to a similar conclusion that $97 \%$ of companies show commitment to CSR related activities.

\section{Perceptions and Perspectives on CSR}

On perceptions and perspectives on CSR, Adu-Boahen et. al. (2014) examined managers' views on companies' CSR and how this affects their attitudes towards such practices. Ofori (2010) explored the perspectives of top executives on CSR, and found that top executives viewed CSR as a critical organisational function. Values driven CSR practices also appealed more to the top executives of the companies studied, as has been established by Schmeltz (2012) in Denmark. Besides, Kasum, Aveh and Salman (2016) examined business stakeholders' (managers, owners, customers, experts) perceptions of CSR, specifically looking at international corporations operating in Ghana. In consonance with the research finding by Cone Communications (2015), the study reported that Ghanaian stakeholders expect foreign companies to be responsible and responsive to CSR.

\section{Conceptual/Review}

A conceptual paper by Dartey-Baah and Amponsah-Tawiah (2011) argues that there are limitations in the applicability of Western CSR theories in African societies. On the other hand, Amponsah-Tawiah and DarteyBaah (2011) discuss the usage of the concept of CSR in the Ghanaian mining sector. A later study by AmponsahTawiah and Dartey-Baah (2012) examined the role of CSR and organisational Health and Safety (OHS). The paper advanced a positive relationship between CSR-OHS and observed that an improved CSR and OHS practices lead to improvement in health, maternal care, environmental sustainability and other key critical areas of development. Another conceptual paper by Tuokuu and Amponsah-Tawiah (2016) examined critical issues and debates on CSR and argues that pursing the developmental agenda of Africa through the benevolence of Multinational Corporations (MNCs) is practically not sustainable. The authors advanced a multi-stakeholder approach to CSR to drive a sustainable and inclusive development. Ndzibah (2009) looked at CSR within the context of e-waste and scavenging activities. The paper argued that due to the cost of recycling in home countries, MNCs exploit legal loopholes in developing country contexts to dump recyclable waste (electronic items such as monitors and TV sets and other inferior products) in subsidiary countries, in the name of CSR. The study recommended import restrictions on inferior and second hand products to curb the negative effects of dumping sub-standard goods in Ghana. From an impression management perspective, Hinson et. al. (2017) reviewed extant literature on CSR within the context of International Business, to specifically highlight thematic areas, methodological approaches and research gaps that need scholarly attention. Out of the total number of 27 published journal articles reviewed, only 5 articles (18.5\%) focused on CSR within the context of IB.

It can be seen from the studies reviewed above, that, there have been contributions to the CSR literature from scholars and researchers in Ghana. However, considering the number of research studies identified and the areas 
covered, CSR research in Ghana is still underdeveloped. An analysis of the extant literature suggests that sectors such as mining (e.g. Andrews, 2016) and banking (e.g. Hinson et. al., 2016) have been very dominant in CSR studies in Ghana. Surprisingly, few attempts have focused on literature reviews and conceptual papers. The only review identified, Hinson et. al. (2017), focused on CSR within the context of International Business (IB). In this review, only 5 articles (18.5\%) focused on CSR within the context of IB. Clearly, no study has comprehensively assessed the various streams of research on CSR in Ghana. This is the first attempt to bring together the highly dispersed studies across the various CSR disciplines. Based on the literature reviewed, therefore, this current study aims to identify, analyse and integrate research domains in the new bourgeoning literature on CSR in Ghana to understand how the concept has developed and matured. Research streams and perspectives on CSR in Ghana contribute to the CSR literature in terms of literature review and provide foundations for future research agenda. The study addresses this broad research question: What are the research streams and perspectives on CSR in Ghana?

\section{Methodology}

This study sought to examine the current state of Corporate Social Responsibility (CSR) research in Ghana. In order to achieve this objective, databases and search engines for CSR were identified followed by a comprehensive search of academic papers on CSR specifically in the Ghanaian context. Since this is the first investigation to assemble existing research studies on CSR in Ghana, the search was not limited by date. This is in line with extensive reviews by Golob et. al. 2013 and Verk and Golob (2013), that sought to compile all readily available research papers on CSR related topics. All published academic papers on CSR in Ghana (only articles that featured in academic journals) were considered for inclusion in the study. Following scholars who have done similar reviews (e.g. Belal \& Momin, 2009), the study excluded other publications such as book chapters, articles in conference proceedings and reports. Belal and Momin (2009), for instance argue that most academic papers go through rigorous screening processes by independent experts thereby providing most up-to- date and authoritative information on CSR. A key word based strategy was adopted to ensure that articles retrieved and included in the analysis were on and about CSR (e.g. De Baker et. al., 2005). Key words used to search for titles and abstracts, and subsequently the academic papers across all the disciplinary perspectives on CSR included corporate social responsibility/social responsibility/corporate responsibility in Ghana, corporate social responsibility communication/social responsibility communication, corporate responsibility communication in Ghana and CSR/CSR communication in Ghana. Three key online databases served as the sources of the articles: EBSCOhost, Emerald Insights and Business Source Complete. Previous reviews relied on these databases which make them relevant to CSR related studies (e.g. Golob et. al. 2013). Some of the papers were also sourced from Google search engine (the study excluded local Ghanaian print journals). A total of 52 abstracts were initially screened after which 47 full papers were subsequently retrieved for detailed analysis. Five of the abstracts were excluded from the study after several unsuccessful attempts to locate the full papers in online databases. The analysis of the research domains within the field of CSR in Ghana was based on the 47 available articles (which eventually formed the final sample), published up to the year 2017. This particular year was selected because the study was conducted in 2018 (the search and review processes were from January 5, 2018 to June 5, 2018).

\section{Procedure}

All the 47 articles that fit the criteria for inclusion were read and critically reviewed. The study relied on content analysis procedures drawn from the existing literature to determine categories that ought to be identified in the articles (e.g. Kripendoff, 2004). Content analysis has been widely utilised in systematic CSR reviews (e.g. Crane \& Glozer, 2016) and CSR related studies in different country contexts (e.g. Frostenson, et. al. 2011 in Sweden). Golob et. al. 2013 for instance adopted content analysis strategies to assess 90 CSR communication papers in their study. The articles were manually coded and categorised into themes (based on CSR theories/concepts in the literature and the research question) to identify the research domains that dominate the CSR literature in Ghana. First, the 47 papers were categorised based on Ihlen et. al.'s. (2011) CSR research fields: (Public Relations and Communication, Marketing Communication and Organisation and Management Studies). The papers were further analysed to identify the dominant orientations, research streams and perspectives. For instance, the study adopted Lockett et. al. 's (2006) dichotomy between empirical (whether qualitative, quantitative, mixed) and theoretical papers to classify the articles as such, and to determine whether these articles are exploratory, descriptive or explanatory (Creswell, 2014). Visser (2008) has used this method in developing country contexts. Following Carroll (1999) and Lockett et. al. (2006), CSR issues were categorised into five thematic areas: economic, social, environmental, ethics and stakeholder. The study also followed the reasoning behind Golob et. al.'s (2013) differentiation between the nature of CSR research and identified three key areas: disclosure, outcome, and process. Two independent experts in CSR assisted with all the categorisations as a check strategy and to reconcile any differences if any (e.g. Creswell, 2014). 
Findings and Discussion

This section presents and discusses the findings derived from the study which sought to map the research domains on CSR in the Ghanaian context. The section addresses the research question of the study: What are the research streams and perspectives on CSR in Ghana? As noted earlier, the review was not limited by date. However, the study found 47 available academic articles on CSR published between 2007 and 2017 (See Table 1). The earliest paper retrieved was published in 2007 while the latest in 2017. The search and review processes were conducted from January to June, 2018, and therefore, the year 2017 was the latest at the time the study was being conducted.

Table 1: Published articles on CSR in Ghana

\begin{tabular}{|c|c|c|c|}
\hline $\begin{array}{l}\text { Author (s)/Year of } \\
\text { Publication/Paper } \\
\text { Type }\end{array}$ & $\begin{array}{l}\text { Focus of } \\
\text { article/Sector }\end{array}$ & $\begin{array}{l}\text { Methodology/Theoretical } \\
\text { Approach }\end{array}$ & Journal \\
\hline $\begin{array}{l}\text { Amponsah-Tawiah and } \\
\text { Mensah, } 2017 \\
\text { (Research, Exploratory) }\end{array}$ & $\begin{array}{l}\text { CSR and } \\
\text { occupational health } \\
\text { and safety } \\
\text { Mining }\end{array}$ & $\begin{array}{l}\text { Qualitative } \\
\text { N/A }\end{array}$ & $\begin{array}{l}\text { Journal of Global } \\
\text { Responsibility }\end{array}$ \\
\hline $\begin{array}{l}\text { Ansong, } 2017 \\
\text { (Research, } \\
\text { Explanatory) }\end{array}$ & $\begin{array}{l}\text { CSR and financial } \\
\text { performance } \\
\text { Multi-industry }\end{array}$ & $\begin{array}{l}\text { Quantitative } \\
\text { Stakeholder Theory }\end{array}$ & $\begin{array}{l}\text { Cogent Business and } \\
\text { Management }\end{array}$ \\
\hline $\begin{array}{l}\text { Boateng and Abdul- } \\
\text { Hamid, } 2017 \\
\text { (Research, Exploratory) }\end{array}$ & $\begin{array}{l}\text { Online CSR } \\
\text { communication } \\
\text { Telecommunications }\end{array}$ & $\begin{array}{l}\text { Qualitative, } \\
\text { Impression management } \\
\text { theory (Bolino et. al. } \\
\text { 2008) }\end{array}$ & $\begin{array}{l}\text { Journal of Information, } \\
\text { Communication and Ethics in } \\
\text { Society }\end{array}$ \\
\hline $\begin{array}{l}\text { Boso et. al. } 2017 \\
\text { (Research) }\end{array}$ & $\begin{array}{l}\text { Drivers of CSR } \\
\text { Mining }\end{array}$ & $\begin{array}{l}\text { Mixed } \\
\text { Frederiksen's (2009) CSR } \\
\text { theory }\end{array}$ & $\begin{array}{l}\text { International Journal of } \\
\text { corporate social responsibility }\end{array}$ \\
\hline $\begin{array}{l}\text { Famiyeh, } 2017 \\
\text { (Research, } \\
\text { Explanatory) }\end{array}$ & $\begin{array}{l}\text { CSR and financial } \\
\text { performance } \\
\text { Multi-industry }\end{array}$ & $\begin{array}{l}\text { Quantitative } \\
\text { Stakeholder Theory } \\
\text { Propose a model on CSR } \\
\text { and financial performance }\end{array}$ & Social Responsibility Journal \\
\hline $\begin{array}{l}\text { Hinson et. al. } 2017 \\
\text { (Literature Review) }\end{array}$ & $\begin{array}{l}\text { CSR and } \\
\text { International } \\
\text { Business }\end{array}$ & $\begin{array}{l}\text { Literature Review } \\
\text { N/A }\end{array}$ & $\begin{array}{l}\text { International Journal of } \\
\text { Corporate Social } \\
\text { Responsibility }\end{array}$ \\
\hline $\begin{array}{l}\text { Welbeck, } 2017 \\
\text { (Research, Descriptive) }\end{array}$ & $\begin{array}{l}\text { Organisational } \\
\text { antecedents and } \\
\text { CSR disclosure } \\
\text { Multi-industry }\end{array}$ & $\begin{array}{l}\text { Quantitative } \\
\text { Institutional theory } \\
\text { Proposes conceptual } \\
\text { model on CSR disclosure } \\
\text { and institutional } \\
\text { characteristics }\end{array}$ & $\begin{array}{l}\text { Meditari Accountancy } \\
\text { Research }\end{array}$ \\
\hline $\begin{array}{l}\text { Agyemang and } \\
\text { Ansong, } 2016 \\
\text { (Research, } \\
\text { Explanatory) }\end{array}$ & $\begin{array}{l}\text { CSR and financial } \\
\text { performance } \\
\text { Multi-industry }\end{array}$ & $\begin{array}{l}\text { Quantitative, } \\
\text { Propose a framework on } \\
\text { CSR and financial } \\
\text { performance }\end{array}$ & $\begin{array}{l}\text { Journal of Global } \\
\text { Responsibility }\end{array}$ \\
\hline $\begin{array}{l}\text { Andrews, } 2016 \\
\text { (Research, Exploratory) }\end{array}$ & $\begin{array}{l}\text { Challenges of CSR } \\
\text { Mining }\end{array}$ & $\begin{array}{l}\text { Qualitative } \\
\text { N/A }\end{array}$ & Resources Policy \\
\hline $\begin{array}{l}\text { Boateng, } 2016 \\
\text { (Research, Descriptive) }\end{array}$ & $\begin{array}{l}\text { Online CSR } \\
\text { communication } \\
\text { Banking } \\
\end{array}$ & $\begin{array}{l}\text { Quantitative } \\
\text { N/A }\end{array}$ & $\begin{array}{l}\text { South African Journal of } \\
\text { Communication Theory and } \\
\text { Research }\end{array}$ \\
\hline $\begin{array}{l}\text { Hinson et. al. } 2016 \\
\text { (Research, Descriptive) }\end{array}$ & $\begin{array}{l}\text { Customers } \\
\text { preferences and } \\
\text { reactions to CSR } \\
\text { Banking }\end{array}$ & $\begin{array}{l}\text { Quantitative } \\
\text { Draw on Carroll's (1999) } \\
\text { CSR framework }\end{array}$ & $\begin{array}{l}\text { African Journal of Business } \\
\text { Ethics }\end{array}$ \\
\hline $\begin{array}{l}\text { Kasum et. al. } 2016 \\
\text { (Research, Descriptive } \\
\text { ) }\end{array}$ & $\begin{array}{l}\text { Stakeholder } \\
\text { perception of CSR } \\
\text { Multi-industry }\end{array}$ & $\begin{array}{l}\text { Quantitative } \\
\text { N/A }\end{array}$ & $\begin{array}{l}\text { Issues in Social and } \\
\text { Environmental Accounting }\end{array}$ \\
\hline $\begin{array}{l}\text { Okoe and Boateng } \\
2016 \\
\text { (Research, Exploratory) }\end{array}$ & $\begin{array}{l}\text { CSR information } \\
\text { needs of customers } \\
\text { Microfinance }\end{array}$ & $\begin{array}{l}\text { Qualitative, } \\
\text { Wilson's (1981) concept } \\
\text { of information needs }\end{array}$ & $\begin{array}{l}\text { Journal of Information, } \\
\text { Communication and Ethics in } \\
\text { Society }\end{array}$ \\
\hline
\end{tabular}




\begin{tabular}{|c|c|c|c|}
\hline $\begin{array}{l}\text { Author (s)/Year of } \\
\text { Publication/Paper } \\
\text { Type }\end{array}$ & $\begin{array}{l}\text { Focus of } \\
\text { article/Sector }\end{array}$ & $\begin{array}{l}\text { Methodology/Theoretical } \\
\text { Approach }\end{array}$ & Journal \\
\hline $\begin{array}{l}\text { Opoku Appiah et. al. } \\
2016 \\
\text { (Research, Descriptive) }\end{array}$ & $\begin{array}{l}\text { Online CSR } \\
\text { communication } \\
\text { Insurance }\end{array}$ & $\begin{array}{l}\text { Quantitative } \\
\text { Stakeholder Theory }\end{array}$ & $\begin{array}{l}\text { Journal of Communication } \\
\text { Management }\end{array}$ \\
\hline $\begin{array}{l}\text { Simpson et. al. } 2016 \\
\text { (Research, Exploratory) }\end{array}$ & $\begin{array}{l}\text { Internal audit } \\
\text { function and CSR } \\
\text { assurance } \\
\text { Multi-industry }\end{array}$ & $\begin{array}{l}\text { Qualitative, } \\
\text { N/A }\end{array}$ & Social Responsibility Journal \\
\hline $\begin{array}{l}\text { Tuokuu and } \\
\text { Amponsah-Tawiah, } \\
2016 \\
\text { (Conceptual) }\end{array}$ & $\begin{array}{l}\text { Is CSR an } \\
\text { alternative to } \\
\text { government? }\end{array}$ & $\begin{array}{l}\text { Conceptual } \\
\text { Stakeholder Theory }\end{array}$ & $\begin{array}{l}\text { Journal of Global } \\
\text { Responsibility }\end{array}$ \\
\hline $\begin{array}{l}\text { Abugre and Nyuur, } \\
2015 \\
\text { (Research, Descriptive) }\end{array}$ & $\begin{array}{l}\text { Organisations' } \\
\text { commitment to and } \\
\text { communication of } \\
\text { CSR } \\
\text { Multi-industry }\end{array}$ & $\begin{array}{l}\text { Quantitative, } \\
\text { Legitimacy/Stakeholder }\end{array}$ & Social Responsibility Journal \\
\hline $\begin{array}{l}\text { Alomenu et. al. } 2015 \\
\text { (Research, Exploratory) }\end{array}$ & $\begin{array}{l}\text { Influence of CSR } \\
\text { on Clients' } \\
\text { patronage of Banks } \\
\text { Banking }\end{array}$ & $\begin{array}{l}\text { Qualitative } \\
\text { N/A }\end{array}$ & $\begin{array}{l}\text { Journal of Entrepreneurship } \\
\text { and Business }\end{array}$ \\
\hline $\begin{array}{l}\text { Amo-Mensah and } \\
\text { Tench } 2015 \\
\text { (Research, Exploratory) }\end{array}$ & $\begin{array}{l}\text { Extent and type of } \\
\text { online CSR } \\
\text { communication } \\
\text { Multi-industry }\end{array}$ & $\begin{array}{l}\text { Qualitative } \\
\text { Stakeholder/Legitimacy } \\
\text { Develops a framework on } \\
\text { online CSR } \\
\text { communication }\end{array}$ & Tripodos \\
\hline $\begin{array}{l}\text { Anim and } \\
\text { Agbemabiese, } 2015 \\
\text { (Research, Descriptive) }\end{array}$ & $\begin{array}{l}\text { The influence of } \\
\text { CSR on consumer } \\
\text { purchase decisions } \\
\text { Telecommunications }\end{array}$ & $\begin{array}{l}\text { Quantitative } \\
\text { Carroll's (1991) CSR } \\
\text { model }\end{array}$ & $\begin{array}{l}\text { International Journal of } \\
\text { Scientific and Technology } \\
\text { Research }\end{array}$ \\
\hline $\begin{array}{l}\text { Dartey-Baah et. al. } \\
2015 \\
\text { (Research, Exploratory) }\end{array}$ & $\begin{array}{l}\text { CSR and national } \\
\text { development } \\
\text { Multi-industry }\end{array}$ & $\begin{array}{l}\text { Qualitative } \\
\text { Stakeholder theory } \\
\text { Propose a framework on } \\
\text { CSR and national } \\
\text { development }\end{array}$ & Africa Today \\
\hline $\begin{array}{l}\text { Marfo et. al. } 2015 \\
\text { (Research, } \\
\text { Explanatory) }\end{array}$ & $\begin{array}{l}\text { Financial resource } \\
\text { availability and } \\
\text { CSR } \\
\text { Multi-industry }\end{array}$ & $\begin{array}{l}\text { Quantitative, } \\
\text { Draw on Secchi's (2007) } \\
\text { CSR theories }\end{array}$ & $\begin{array}{l}\text { International Journal of } \\
\text { Academic Research in } \\
\text { Accounting, Finance and } \\
\text { Management Sciences }\end{array}$ \\
\hline $\begin{array}{l}\text { Nyuur et. al. } 2015 \\
\text { (Research, } \\
\text { Explanatory) }\end{array}$ & $\begin{array}{l}\text { The impact of } \\
\text { Foreign Direct } \\
\text { Investment and CSR } \\
\text { Multi-industry }\end{array}$ & $\begin{array}{l}\text { Quantitative, } \\
\text { Propose a model on FDI- } \\
\text { CSR relationship }\end{array}$ & $\begin{array}{l}\text { Thunderbird International } \\
\text { Business Review }\end{array}$ \\
\hline $\begin{array}{l}\text { Abugre, } 2014 \\
\text { (Research, Descriptive) }\end{array}$ & $\begin{array}{l}\text { Managerial role in } \\
\text { CSR } \\
\text { Multi-industry }\end{array}$ & $\begin{array}{l}\text { Quantitative } \\
\text { N/A }\end{array}$ & Corporate Governance \\
\hline $\begin{array}{l}\text { Adu-Boahen et. al. } \\
2014 \\
\text { (Research) }\end{array}$ & $\begin{array}{l}\text { Managers attitudes } \\
\text { towards CSR } \\
\text { Multi-industry }\end{array}$ & $\begin{array}{l}\text { Mixed } \\
\text { N/A }\end{array}$ & $\begin{array}{l}\text { European Journal of Business } \\
\text { and Social Science }\end{array}$ \\
\hline $\begin{array}{l}\text { Ayogyam et. al. } 2014 \\
\text { (Research, } \\
\text { Explanatory) }\end{array}$ & $\begin{array}{l}\text { The effect of CSR } \\
\text { on brands } \\
\text { Multi-industry }\end{array}$ & $\begin{array}{l}\text { Quantitative, } \\
\text { Propose a model on CSR } \\
\text { and brands }\end{array}$ & $\begin{array}{l}\text { Canadian Center of Science } \\
\text { and Education }\end{array}$ \\
\hline
\end{tabular}




\begin{tabular}{|c|c|c|c|}
\hline $\begin{array}{l}\text { Author (s)/Year of } \\
\text { Publication/Paper } \\
\text { Type }\end{array}$ & $\begin{array}{l}\text { Focus of } \\
\text { article/Sector }\end{array}$ & $\begin{array}{l}\text { Methodology/Theoretical } \\
\text { Approach }\end{array}$ & Journal \\
\hline $\begin{array}{l}\text { Nyuur et. al. } 2014 \\
\text { (Research) }\end{array}$ & $\begin{array}{l}\text { Hindering and } \\
\text { promoting factors of } \\
\text { CSR } \\
\text { Multi-industry }\end{array}$ & $\begin{array}{l}\text { Mixed } \\
\text { Smit (2009) CSR value } \\
\text { chain/Stakeholder Theory }\end{array}$ & $\begin{array}{l}\text { African Journal of Economic } \\
\text { and Management studies }\end{array}$ \\
\hline $\begin{array}{l}\text { Ofori et. al. } 2014 \\
\text { (Research, Descriptive) }\end{array}$ & $\begin{array}{l}\text { CSR and Financial } \\
\text { Performance } \\
\text { Banking }\end{array}$ & $\begin{array}{l}\text { Quantitative } \\
\text { N/A }\end{array}$ & Acta Commercii \\
\hline $\begin{array}{l}\text { Andrews, } 2013 \\
\text { (Research, Exploratory) }\end{array}$ & $\begin{array}{l}\text { Community } \\
\text { expectations from } \\
\text { Ghana's oil find } \\
\text { Mining }\end{array}$ & $\begin{array}{l}\text { Qualitative } \\
\text { N/A }\end{array}$ & Africa Today \\
\hline $\begin{array}{l}\text { Julian and Ofori- } \\
\text { Dankwa (2013) } \\
\text { (Research, } \\
\text { Explanatory) }\end{array}$ & $\begin{array}{l}\text { Financial resource } \\
\text { availability and } \\
\text { CSR } \\
\text { Multi-industry }\end{array}$ & $\begin{array}{l}\text { Quantitative } \\
\text { Slack resources theory }\end{array}$ & Strategic Management Journal \\
\hline $\begin{array}{l}\text { Lichtenstein } \text { et. al. } \\
2013 \\
\text { (Research, Descriptive) }\end{array}$ & $\begin{array}{l}\text { CSR architecture } \\
\text { and project } \\
\text { alignments } \\
\text { Construction }\end{array}$ & $\begin{array}{l}\text { Quantitative } \\
\text { Stakeholder Theory }\end{array}$ & $\begin{array}{l}\text { Journal of Engineering Design } \\
\text { and Technology }\end{array}$ \\
\hline $\begin{array}{l}\text { Owusu-Ansah, } 2013 \\
\text { (Research, Exploratory) }\end{array}$ & $\begin{array}{l}\text { CSR in Ghana } \\
\text { Multi-industry }\end{array}$ & $\begin{array}{l}\text { Qualitative, } \\
\text { N/A }\end{array}$ & $\begin{array}{l}\text { International Review of } \\
\text { Management and Marketing }\end{array}$ \\
\hline $\begin{array}{l}\text { Amponsah-Tawiah and } \\
\text { Dartey-Baah (2012) } \\
\text { (Conceptual) }\end{array}$ & $\begin{array}{l}\text { CSR and } \\
\text { occupational health } \\
\text { and safety }\end{array}$ & $\begin{array}{l}\text { Conceptual } \\
\text { Propose a model on CSR- } \\
\text { OHS }\end{array}$ & $\begin{array}{l}\text { Journal of Global } \\
\text { Responsibility }\end{array}$ \\
\hline $\begin{array}{l}\text { Hinson and Kodua, } \\
2012 \\
\text { (Research, Exploratory) }\end{array}$ & $\begin{array}{l}\text { CSR practices of } \\
\text { foreign and local } \\
\text { companies } \\
\text { Telecommunications }\end{array}$ & $\begin{array}{l}\text { Qualitative } \\
\text { Maignan et. al.'s (2005) } \\
\text { CSR Framework }\end{array}$ & $\begin{array}{l}\text { International Journal of Law } \\
\text { and Management }\end{array}$ \\
\hline $\begin{array}{l}\text { Kuada and Hinson, } \\
2012 \\
\text { (Research, Descriptive) }\end{array}$ & $\begin{array}{l}\text { CSR practices of } \\
\text { foreign and local } \\
\text { companies } \\
\text { Multi-industry }\end{array}$ & $\begin{array}{l}\text { Quantitative } \\
\text { N/A }\end{array}$ & $\begin{array}{l}\text { Thunderbird International } \\
\text { Business Review }\end{array}$ \\
\hline $\begin{array}{l}\text { Mahmoud and Hinson, } \\
2012 \\
\text { (Research, Descriptive) }\end{array}$ & $\begin{array}{l}\text { Market orientation, } \\
\text { innovation and CSR } \\
\text { Telecommunications }\end{array}$ & $\begin{array}{l}\text { Quantitative } \\
\text { Draws on Kolar's (2006) } \\
\text { model on market } \\
\text { orientation and other } \\
\text { measures }\end{array}$ & Social Responsibility Journal \\
\hline $\begin{array}{l}\text { Mares, } 2012 \\
\text { (Research, Exploratory) }\end{array}$ & $\begin{array}{l}\text { CSR and } \\
\text { compliance with the } \\
\text { law } \\
\text { Mining }\end{array}$ & $\begin{array}{l}\text { Qualitative, } \\
\text { N/A }\end{array}$ & Business and Society Review \\
\hline $\begin{array}{l}\text { Amponsah-Tawiah and } \\
\text { Dartey-Baah (2011) } \\
\text { (Conceptual) }\end{array}$ & CSR in Ghana & $\begin{array}{l}\text { Conceptual } \\
\text { N/A }\end{array}$ & $\begin{array}{l}\text { International Journal of } \\
\text { Business and Social Science }\end{array}$ \\
\hline $\begin{array}{l}\text { Dartey-Baah and } \\
\text { Amponsah-Tawiah, } \\
2011 \\
\text { (Conceptual) }\end{array}$ & $\begin{array}{l}\text { The limits of } \\
\text { western CSR } \\
\text { theories in Africa }\end{array}$ & Conceptual & $\begin{array}{l}\text { International Journal of } \\
\text { Business and Social Science }\end{array}$ \\
\hline $\begin{array}{l}\text { Hinson, } 2011 \\
\text { (Research, Exploratory) }\end{array}$ & $\begin{array}{l}\text { Online CSR } \\
\text { communication } \\
\text { Banking }\end{array}$ & $\begin{array}{l}\text { Qualitative, } \\
\text { Stakeholder/Legitimacy } \\
\text { Proposes a framework on } \\
\text { online CSR } \\
\text { communication }\end{array}$ & $\begin{array}{l}\text { Journal of Information, } \\
\text { Communication and Ethics in } \\
\text { Society }\end{array}$ \\
\hline
\end{tabular}




\begin{tabular}{|c|c|c|c|}
\hline $\begin{array}{l}\text { Author (s)/Year of } \\
\text { Publication/Paper } \\
\text { Type }\end{array}$ & $\begin{array}{l}\text { Focus of } \\
\text { article/Sector }\end{array}$ & $\begin{array}{l}\text { Methodology/Theoretical } \\
\text { Approach }\end{array}$ & Journal \\
\hline $\begin{array}{l}\text { Puplampu and } \\
\text { Dashwood, } 2011 \\
\text { (Research, Exploratory) }\end{array}$ & $\begin{array}{l}\text { Organisational } \\
\text { antecedents and } \\
\text { CSR } \\
\text { Multi-industry }\end{array}$ & $\begin{array}{l}\text { Qualitative } \\
\text { N/A }\end{array}$ & Business and Society Review \\
\hline $\begin{array}{l}\text { Hinson et. al., } 2010 \\
\text { (Research, } \\
\text { Explanatory) }\end{array}$ & $\begin{array}{l}\text { Online CSR } \\
\text { communication } \\
\text { Banking }\end{array}$ & $\begin{array}{l}\text { Quantitative } \\
\text { Stakeholder/Legitimacy }\end{array}$ & $\begin{array}{l}\text { International Journal of Bank } \\
\text { Marketing }\end{array}$ \\
\hline $\begin{array}{l}\text { Ofori, } 2010 \\
\text { (Research, Exploratory) }\end{array}$ & $\begin{array}{l}\text { Managers attitudes } \\
\text { towards CSR } \\
\text { Multi-industry }\end{array}$ & $\begin{array}{l}\text { Qualitative, } \\
\text { N/A }\end{array}$ & $\begin{array}{l}\text { Global Partnership } \\
\text { Management Journal }\end{array}$ \\
\hline $\begin{array}{l}\text { Yankson, } 2010 \\
\text { (Research, Exploratory) }\end{array}$ & $\begin{array}{l}\text { CSR in the mining } \\
\text { sector } \\
\text { Mining }\end{array}$ & $\begin{array}{l}\text { Qualitative } \\
\text { N/A }\end{array}$ & Development in Practice \\
\hline $\begin{array}{l}\text { Ndzibah, } 2009 \\
\text { (Conceptual) }\end{array}$ & $\begin{array}{l}\text { CSR, e-waste and } \\
\text { scavenging } \\
\text { activities }\end{array}$ & $\begin{array}{l}\text { Conceptual } \\
\text { N/A }\end{array}$ & $\begin{array}{l}\text { Management of } \\
\text { Environmental Quality: An } \\
\text { International Journal }\end{array}$ \\
\hline $\begin{array}{l}\text { Hilson, } 2007 \\
\text { (Research) }\end{array}$ & $\begin{array}{l}\text { CSR in the mining } \\
\text { sector } \\
\text { Mining }\end{array}$ & $\begin{array}{l}\text { Qualitative, } \\
\text { N/A }\end{array}$ & $\begin{array}{l}\text { Greener Management } \\
\text { International }\end{array}$ \\
\hline $\begin{array}{l}\text { Ofori and Hinson } 2007 \\
\text { (Research, Exploratory) }\end{array}$ & $\begin{array}{l}\text { Perspectives on } \\
\text { CSR } \\
\text { Multi-industry }\end{array}$ & $\begin{array}{l}\text { Qualitative } \\
\text { N/A }\end{array}$ & $\begin{array}{l}\text { The International Journal of } \\
\text { Business in Society }\end{array}$ \\
\hline
\end{tabular}

Source (Author: Compiled for this study)

\section{Research rate}

From the Table above, two articles were published in 2007 (4.26\%), three in 2010 representing 6.38\%, one in 2009 constituting 2.13\% and four in 2011 and 2013 representing 8.51\% apiece. Again, in 2012 and 2014, five articles each were identified. This represents $21.28 \%$ of the total published articles analysed. The year 2015 and 2017 recorded seven published articles each amounting to $14.89 \%$ respectively, while 2016 had nine papers $(19.15 \%)$. Surprisingly, no published article was recorded in 2008. Although according to Ofori (2010), CSR in Ghana dates back to the 1950's, it appears the onset of CSR research in Ghana is quite a recent phenomenon, since the first online publication identified was in 2007. The evidence suggests that, averagely, there has been a steady growth in CSR research over the study period from a single digit rate of $4.26 \%$ in 2007 , dwindling with a least of zero percentage the following year (2008), maintaining an intermittent two yearly steady growth rate between 2011 to 2017 from a single digit of (8.51\%) through $10.64 \%$ to $14.89 \%$, with 2016 recording the highest published articles. It is worthy to note that the last four years of the period under consideration accounted for approximately sixty percent (59.57\%) of the total articles published between 2007 and 2017, showing a remarkable improvement and interest by researchers in Ghana. Hinson et. al. (2017) for instance confirm that CSR in Ghana developed from the year 2010. It must be emphasised, however, that research studies on CSR in Ghana are much lower when compared with studies in other contexts, for instance in South Africa (Visser, 2006). The findings also revealed that, scholars in Ghana have shared their knowledge in a broad range of journals, providing other researchers with a wide variety of publication options. In terms of journal representation, the analysis, shows, for example that the 47 academic papers appeared in 34 different journals with the highest number of articles featuring in Journal of Global Responsibility and Social Responsibility Journal which had four articles each. The second most frequently listed journal, Journal of Information, Communication and Ethics in Society, had 3 articles; International Journal of Business and Social Science, Business and Society Review, Africa Today, International Journal of Corporate Social Responsibility and Thunderbird International Business Review had two articles each, while the remaining twenty-six journals had one article each. This means that less than a quarter - eight journals (23.53\%) published close to half $(44.68 \%)$ of the total papers analysed with the remaining $76.47 \%$ (twenty-six journals) publishing $55.32 \%$ of the papers.

\section{Disciplinary perspectives}

The research papers were broadly categorised into CSR and CSR communication, and also, into public relations, marketing and organisation and management studies, following Ihlen et. al. (2011). Insights from the study suggest that compared to the extensive literature on CSR in Ghana, very few studies have concentrated on CSR 
communication. This finding lends support to the observations by Ihlen et. al. (2011) and Nielsen and Thomsen (2012) that, generally, literature on the communication aspect of CSR is minimal. From the forty-seven papers analysed thirty-nine (82.98\%) focused on CSR while the remaining eight $(17.02 \%)$ focused on CSR communication. Crucially, research has established that stakeholders increasingly look for information about CSR which requires companies to keep them updated about their social and ethical issues (e.g. Ihlen et. al. (2011). Through communication, companies can show evidence of their CSR commitments to build stakeholder trust and loyalty, in the wake of recent scepticisms and attributions (Edelman, 2018). Of the eight papers that centered on CSR communication, seven (87.5\%) focused on web-based disclosures. Only Welbeck's (2017) study analysed companies' annual reports for CSR information. Due to technological developments, the web presents many opportunities for companies to dialogue or engage with their stakeholders in CSR efforts (Tench \& Amo-Mensah, 2018). At the same time, scholars from Ghana focus on CSR from various academic disciplines. In line with the categorisations by Ihlen et. al. (2011), the vast majority of the research papers, twenty-four, representing $51.06 \%$ focused on marketing (e.g. Hinson et. al. 2016; Mahmoud \& Hinson, 2012; Okoe \& Boateng, 2016), looking at consumer preferences and reactions towards CSR and other customer or brand related CSR studies. Eleven papers $(23.40 \%$ ) centred on public relations or corporate communication within the context of CSR (e.g. Amo-Mensah \& Tench, 2015; Boateng, 2016; Opoku Appiah et. al. 2016); seven articles constituting 14.89\% (e.g. Abugre, 2014; Puplampu and Dashwood, 2011) related to organisation and management studies, emphasising managerial roles in CSR and other institutional characteristics that serve as predictors of CSR, while five papers (10.64\%) were categorised as conceptual/literature review (e.g.Amponsah-Tawiah \& Dartey-Baah, 2012; Hinson et. al. 2017).

\section{Thematic areas}

Following Carroll (1999) and Lockett et. al. (2006), CSR issues in the papers examined were categorised into five thematic areas: economic (profit-oriented), social (general societal well-being), environmental (environmental considerations), ethics (values-driven actions) and stakeholder (relationship with stakeholder groups). For example, the finding by Boateng (2016) that CSR projects primary focused on donations and social projects was categorised under 'social'. Welbeck's (2017) study also concluded that environmental CSR disclosures of companies listed on the GSE were more than social disclosures, and this was categorised under 'environmental'. The articles highlighted all the five thematic areas, however, majority of them (twenty-four) focused on sociallyoriented issues, with particular emphasis on how CSR can contribute to societal development or improving the lives of members within the community (e.g. Yankson, 2010; Hinson et. al. 2016). As expected, social/philanthropic issues including charitable donations and corporate support to education and health related issues seemed to dominate CSR practices and research in Ghana. Many studies in Africa have reached similar conclusions. In Nigeria, for instance, Amaeshi et. al. (2006) revealed that CSR practices are framed within the context of development, particularly to address socio-economic challenges related to health, education and infrastructure as opposed to conceptualisations of CSR in developed countries which focus on environmental and other ethical concerns (e.g. Lockett et. al. 2006). Visser (2008) also observes that responsible business practices in emerging economies particularly in Africa draws heavily on "deep-rooted indigenous cultural traditions of philanthropy" and upon African humanism, what has been widely referred to as Ubuntu (Visser, 2008, p. 481). The next most discussed CSR issues in the papers examined were economic (thirteen papers) followed by stakeholder-oriented dimensions (four). Compared to findings in many developed countries (e.g. Kim et. al. 2010), environmental and ethical CSR themes were not prominent in the studies examined as these had three papers each. The study also followed the reasoning behind Golob et. al.'s (2013) differentiation between the nature of CSR research and identified three key areas: disclosure, outcome, and process. Most of the papers that fell under economic issues assessed the relationship between CSR and financial performance (e.g. Famiyeh, 2017) reflecting outcome -oriented streams of research. Other CSR topics that were covered in the papers were CSR reporting practices or disclosure streams of research (e.g. Welbeck, 2017), stakeholder preferences and reactions to CSR (e.g. Hinson et. al. 2016), drivers of CSR (e.g.) perceptions and perspectives on CSR (e.g. Kasum et. al. 2016) the nature of CSR practices (e.g. Amponsah-Tawiah \& Dartey-Baah (2011) and factors that promote or hinder CSR practices (e.g. Nyuur et. al. 2014).

\section{Methodologies}

Another important revelation from the study was that, CSR researchers in Ghana have focused more on empirical dimensions of CSR. There was an unequal distribution of theoretical and empirical papers: of the majority of research articles examined, forty-one representing $87.23 \%$ were empirical. There was only one $(2.13 \%)$ literature review and five (10.64\%) theoretical/conceptual studies (See, Table 1). Lockett et. al. (2006) also found that 53\% of published CSR studies between 1992 and 2002 were empirical. However, the study by Verk and Golob (2013) revealed a somewhat different finding. In their study, $86 \%$ of CSR communication papers were theoretical. The analysis showed that although overtime empirical papers increased, this was not the case for theoretical papers. Between 2013 and 2015 and in 2010 and 2017, there was no study with a theoretical focus. The study also found 
a large number of quantitative methods of the empirical studies, consistent with the studies by Belal and Momin (2009) and Lockett et. al. (2006), but contrary to the finding by Hinson et. al. (2017). Out of the forty-one empirical papers, twenty (42.55\%) focused on quantitative methodologies, mostly drawing on survey data and other statistical methods or analysis. Eighteen of the papers $(38.30 \%)$ focused on quantitative methodologies, mostly relying on non-numerical data while three papers $(6.38 \%$ ) focused on mixed methodology (a combination of qualitative and quantitative approaches). In terms of the purposes of research (See table 1), twelve out of the twenty quantitative papers reviewed (25.53\%) were descriptive and sought to look at the characteristics of different stakeholder groups or organisations or industry-related issues to better define CSR practices. The eight (17.02\%) were causal studies that sought to establish cause-effect relationships such as the relationship between CSR and financial performance. The eighteen qualitative studies were exploratory or preliminary research studies that sought to understand more about CSR as a relatively new phenomenon in Ghana, highlighting areas for potential growth. It is important to emphasise that methodologies of some of the papers were not clearly explicated although they could be inferred. From the evidence gathered, it is clear that research orientations of CSR scholars in Ghana reflect a more positivist stance as opposed to interpretive/constructivist thinking. Again, it appears single methodologies (quantitative, quantitative) have generally been given much priority compared to mixed approaches which seemed to be relatively sparse. There was also evidence of a culture of cooperation and partnerships instead of individualism among CSR researchers in Ghana since the findings suggest extensive research collaborative processes. As many as thirty-three papers (70.21\%) were joint studies while fourteen $(29.79 \%)$ fell into the category of individual studies.

\section{Theoretical underpinnings}

Consistent with the findings by Belal and Momin (2009), the study found that generally, the concept of CSR in Ghana is under-theorised. Most of the scholars relied on established theories in the CSR literature including stakeholder, legitimacy, institutional, impression management and slack resources theories (See table 1). Other studies were informed by Western CSR conceptualisations although it has been argued (e.g. Dartey-Baah \& Amponsah-Tawiah, 2011) that such applications may not adequately mirror or reflect conditions and practices in developing economies such as Ghana. The study by Opoku Appiah (2016) and Hinson et. al. (2010) for instance draw on Branco and Rodriques' (2006) online CSR framework, while Anim and Agbemabiese (2015) and Hinson et. al. (2016) rely on Carroll's (1999) CSR construct which was framed in the American context. Very few studies (only nine) proposed models and theoretical concepts relevant to Ghana or Africa. Most of the studies (eighteen of them) were also not underpinned by any theoretical or conceptual framework (e.g. Simpson et. al. 2016). Overall, stakeholder theory came out strongly as the dominant theory (eleven papers) in the articles analysed, consistent with the studies by Crane and Glozer (2016) and Hinson et. al. (2017). Legitimacy theory followed (four papers) as the second theoretical stance the CSR scholars in Ghana draw upon. While stakeholder theory broadens business societal relationship beyond shareholders to include other constituencies "that affect who can affect or is affected by the achievement of the organisation's objectives" (Freeman, 1984, p.46), the legitimacy theory emphasises that actions of businesses "are desirable, proper, or appropriate within some socially constructed system" (Suchman, 1995).

\section{Industry sectors}

At the same time, CSR research studies in Ghana have focused mainly on large multinational or internationally connected companies particularly those in the mining, banking and telecommunications sectors (the most written about sectors). Thus, MNCs lead the CSR agenda in Ghana, as also observed by Amponsah-Tawiah and DarteyBaah (2011) and consistent with the study by Ziek (2009) in the US context. Little data (only two studies were found, Agyemang and Ansong, 2016; Ansong, 2017) exist on CSR in Small and Medium Scale Enterprises (SMEs). Of the forty-one empirical articles analysed, the mining and banking sectors stemmed out predominantly as the focus of CSR research in Ghana, with seven papers each representing a total of $34.15 \%$. This was followed by the telecommunications sector with four papers $(9.76 \%)$. There was a study each in the construction and insurance sectors while twenty-one $(51.22 \%)$ fell under multi-industry studies (studies that focused on many industry sectors). The multi-industry studies particularly focused on companies listed on either the GC100 (e.g. Amo-Mensah \& Tench, 2015), the Ghana Stock exchange (e.g. Marfo et. al. 2015) or the Ghana Business Directory (e.g. Famiyeh, 2016). A considerable number of the studies focused on companies listed on the GC100 (six of them), which is an annual ranking of top 100 companies in Ghana. Studies have shown that companies listed on the GC100 proactively engage in CSR related activities (e.g. Ofori \& Hinson, 2007). The GC100 was introduced in 1998 by the Ghana Investment Promotion Centre (GIPC) to acknowledge successful companies for their outstanding business performance. In 2005, GIPC included CSR weighting in its criteria for inclusion onto the GC100. Specific studies were not found in sectors like manufacturing, trading, pharmaceuticals and health care, energy and agriculture although some appeared in the multi-industry studies. Although this does not necessarily imply the absence of CSR practices in these sectors, they reveal that scholars have not specifically paid attention 
to these sectors in research endeavours.

\section{Conclusion}

The literature demonstrates that CSR reviews that focus on specific countries have not been given scholarly attention. This study sought to identify and synthesise research studies that have been conducted on CSR in Ghana. The comprehensive search identified a total of 47 academic papers published between 2007 and 2017 in thirtyfour different journals. Drawing on content analysis procedures, the articles retrieved that fit the criteria for inclusion were critically examined to map research streams and perspectives. Reviews of the forty-seven papers suggest that, although generally, CSR research in Ghana is quite a recent phenomenon, averagely, there was a steady research growth over the study period. Insights from the analysis show that compared to the extensive literature on CSR in Ghana, literature on the communication aspect of CSR is minimal. It also emerged that generally, the concept of CSR in Ghana is under-theorised. Researchers have focused more on empirical dimensions of CSR focusing particularly on positivist orientations. Again, majority of the research papers focused on marketing research perspectives looking at consumer preferences and reactions towards CSR, among other aspects. Further, although the papers assessed highlighted several key thematic areas of CSR, majority of them focused on socially-oriented or philanthropic issues looking at how CSR can contribute to societal development. Research studies have also focused mainly on large multinational or internationally connected companies particularly those in the mining, banking and telecommunications sectors. These observations in the study are especially significant. Since this is the first investigation that assesses the state of CSR research in Ghana, the findings point to other critical areas of CSR engagements and research that need further exploration. More studies are, for instance, needed in the conceptual or theoretical CSR dimensions, the communication aspect of CSR, and interpretive/constructivist CSR perspectives that may reveal more compelling evidence on the nature of CSR practices in Ghana. There is also more room for scholars to extend CSR research to SMEs and other industry sectors beyond those identified in this study. It is important to emphasise that this study only focused on academic articles retrieved online. It is possible there may be other research studies on CSR in local Ghanaian print journals.

\section{References}

Abugre, J.B. (2014). Managerial role in organizational CSR: Empirical lessons from Ghana. Corporate Governance, 14(1), 104-119.

Abugre, J.B. \& Nyuur, R.B. (2015). Organizations' commitment to and communication of CSR activities: Insights from Ghana. Social Responsibility Journal, 11 (1), 161-178.

Adu-Boahen, K., Inkoom, J.N., Kissah-Korsah, K., Antwi, K.B., Mensah, A.E. \& Ceasar, J.A. (2014) Assessment of management attitudes on corporate social responsibility in Ghana: A case of some selected companies in the Tema metropolis, European Journal of Business and Social Sciences, 2(11), 102-113.

Agyemang, O.S. \& Ansong, A. (2017). Corporate social responsibility and firm performance of Ghanaian SMES: Mediating role of access to capital and firm reputation, Journal of Global Responsibility, 8(1), 47-62.

Alomenu, C., Effah, E.A. \& Kutu-Adu, S.G. (2015). Do corporate social responsibility activities of Ghanaian banks influence corporate clients' patronage?, Journal of Entrepreneurship and Business, 3(2), 50-63.

Amaeshi, K., Adi, A.B.C, Amao, O.O.O. \& Gbechie, C. (2006). Corporate social responsibility in Nigeria: Western mimicry of indigenous influences?. Journal of Corporate Citizenship, 24(winter), 83-99.

Amo-Mensah, M. \& Tench R. (2018). Transnational Corporate Social Responsibility: Fact, fiction or failure, In Tench, R., Sun, W. and Jones, B. (eds.) The critical state of corporate social responsibility in Europe, Critical Studies on Corporate Responsibility, Governance and Sustainability, Vol. 7, Emerald Publishing Limited, UK.

Amo-Mensah, M. \& Tench, R. (2015). In the Club but out of the game - Evaluation of Ghana Club 100 CSR Communication. Tripodos, 37, 13-34.

Amponsah-Tawiah, K. \& Dartey-Baah, K. (2011). Corporate social responsibility in Ghana. International Journal of Business and Social Science, 2(17), pp.107-112.

Amponsah-Tawiah, K. \& Dartey-Baah, K. (2012). CSR-OHS: Expert views, analysis and commentary on two potent contrivances towards achieving MDGs. Journal of Global Responsibility, 3(2), 224-234.

Amponsah-Tawiah, K. \& Mensah, J. (2015). Exploring the link between corporate social responsibility and health and safety in the mines, Journal of Global Responsibility, 6(1), 65-79.

Andrews, N. (2013). Community expectations from Ghana's oil find: Conceptualizing corporate social responsibility as a grassroot-oriented process. Africa Today, 60(1), 55-75.

Andrews, N. (2016). Challenges of corporate social responsibility (CSR) in domestic settings: An exploration of mining regulation vis-à-vis CSR in Ghana. Resources Policy, 47(C), 9-17.

Anim, P.A. \& Agbemabiese, G.C. (2015). The influence of CSR awareness on consumer purchase decision of a telecommunication network in Ghana: A case of La Nkwantanag Madina Municipality, International Journal of Scientific \&Technology Research, 4(2), 8-19. 
Ansong, A. (2017). Corporate social responsibility and firm performance of Ghanaian SMES: The role of stakeholder engagement, Cogent Business \& Management, 4(1), 1333704.

Ayogyam, A., Amo, F., Kyire, L.A. \& Mohammed, H. (2014). The effect of corporate social responsibility on brand building, International Journal of Marketing Studies, 6(3), 126-134.

Belal, A.R. \& Momin, M. (2009). Corporate social reporting (CSR) in emerging economies: A review and future direction. Research in Accounting in Emerging Economies, 9, 119-143.

Boateng, H. (2016). An analysis of corporate social responsibility communication on the websites of banks operating in Ghana. Communicatio, 42(1), 100-118.

Boateng, H. \& Abdul-Hamid, I.K. (2017). An evaluation of corporate social responsibility communication on the websites of telecommunication companies operating in Ghana: Impression management perspectives, Journal of information, Communication and Ethics in Society, 15 (1), 17-31.

Borglund, T., De Geer, H. \& Hallvarsson, M. (2008). Värdeskapande CSR-Hur Företag tar socialt ansvar. Norstedts: Stockholm.

Boso, R.K., Afrane, S.K. \& Inkoom, D.K.B. (2017). Motivations for proving CSR=mediated initiatives in mining communities in Ghana: A multiple-case study, International Journal of Corporate Social Responsibility, 2(7), DOI: $10.1186 / \mathrm{s} 40991-017-0018-8$.

Capriotti, P. \& Moreno, A. (2007). Communicating corporate responsibility through corporate web sites in Spain. Corporate Communications: An International Journal, 12(3), 221-237.

Carroll, A.B. (1999). Corporate social responsibility: Evolution of a definitional construct. Business and Society, $38,268-295$.

Cone Communications (2015). Cone Communications/Ebiquity global CSR study. Retrieved from: http://www.conecomm.com/2015-global-csr-study-press-release (Accessed 2 November 2018).

Crane, A. \& Glozer, S. (2016). Researching corporate social responsibility communication: Themes, Opportunities and challenges. Retrieved from: http://www.online.wiley.com/doi/10.1111/joms.12196/epdf (Accessed 10 April 2018).

Creswell, J.W. (2014). Research design: Qualitative, quantitative and mixed methods approaches. 4th ed. Thousand Oaks, CA: Sage.

Dartey-Baah, K. \& Amponsah-Tawiah, K. (2011). Exploring the limits of western corporate social responsibility theories in Africa. International Journal of Business and Social Science, 2(18), 126-135.

Dartey-Baah, K., Amponsah-Tawiah, K. \& Agbeibor, V. (2015). Corporate social responsibility in Ghana's national development. Africa Today, 62(2), 70-93.

De Baker, F.G.A., Groenewegen, P. \& den Hond, F. (2005). Bibliometric analysis of 30 years of research and theory on corporate social responsibility and corporate social performance, Business \& Society, 44(3), 283317.

Edelman (2018) 2018 Edelman Trust Barometer. Retrieved from: http://www.edelman.com/trust-barometer (Accessed 21 January 2018).

Elkington, J. (1998). Cannibals with forks: The triple bottom line of the $21^{\text {st }}$ century business. Gabriola Island: New Society Publishers.

Famiyeh, S. (2017). Corporate social responsibility and firm's performance: Empirical evidence, Social responsibility Journal, 13(2), 390-406.

Freeman, R.E. (1984). Strategic Management: A Stakeholder Approach. Boston: Pitman.

Golob, U., Podnar, K., Elving, W.J., Nielsen, A. E., Thomsen, C. and Shultz, F. (2013) CSR communication: Quo vadis?. Corporate Communications: An International Journal, 18(2), 176-192.

Hilson, G. (2007). Championing the rhetoric: Corporate social responsibility in the Ghanaian mining sector. Greener Management International, 53, 43-56.

Hinson, R. (2011). Online CSR reportage of award-winning versus non award-winning banks in Ghana. Journal of Information, Communication and Ethics in Society, 9(2), 102-115.

Hinson, R. \& Kodua, P. (2012). Examining the marketing-corporate social responsibility nexus. International Journal of Law and Management, 54(5), 332-344.

Hinson, R.E., Avornyo, F., Kuada, J. \& Asante, F.A. (2017). Corporate social responsibility and international business: Examining the nexus and gaps from a developing economy perspective, Journal of Corporate Social Responsibility, 2(5), DOI: 10.1186/s4099-017-0016-x

Hinson, R., Boateng, R. \& Madichie, N. (2010) Corporate social responsibility activity reportage on bank websites in Ghana. International Journal of Bank Marketing, 28(7), 498-518.

Hinson, R.E., Renner, A. \& van Zyl, H. (2016). Bank customers' preferences and responses to corporate social responsibility (CSR) initiatives in Ghana, African Journal of Business Ethics, 10(1), 1-18.

Ihlen Ø., Barlett, J. L. \& May, S. (2011). Corporate social responsibility and communication. In: Ihlen Ø., Barlett, J.L. and May, S. (eds.) The handbook of communication and corporate social responsibility. West Sussex, UK: Wiley, 1-22. 
Julian, S. D. \& Ofori-Dankwa, J. C. (2013). Financial resources availability and corporate social responsibility expenditures in Sub-Saharan economy: The institutional difference hypothesis. Strategic Management Journal, 34(11), 1314-1330.

Kasum, A.S., Aveh, K.F.\& Salman, R.T. (2016). Corporate social responsibility (CSR): Stakeholders' perception of foreign corporations in Ghana, Issues in Social and Environmental Accounting, 10(2), 21-44.

Kim, D., Kang, S. \& Nam, Y. (2010). An analysis of corporate environmental responsibility on the global corporate web sites and their dialogic principles. Public Relations Review, 36(3), 285-288.

Krippendorff, K. (2004). Content Analysis: An introduction to its methodology. 2nd ed. Thousand Oaks, CA: Sage.

Kuada, J. \& Hinson, R. (2012). Corporate social responsibility (CSR) practices of foreign and local companies in Ghana. Thunderbird International Business Review, 54(4), 521-536.

Lichtenstein, S., Badu, E., Owusu-Manu, D., Edwards, D.J. \& Holt, G.D. (2013). Corporate social responsibility architecture and project alignments: A study of the Ghanaian construction industry. Journal of Engineering Design and Technology, 11(3), 334-353.

Lockett, A., Moon, J. \& Visser, W. (2006). Corporate social responsibility in management research: Focus, nature, salience and sources of influence, Journal of Management Studies, 43(1), 115-136.

Mahmoud, M. \& Hinson, R. (2012). Market orientation, innovation and corporate social responsibility practices in Ghana's telecommunication sector. Social Responsibility Journal, 8(3), 327-346.

Mares, R. (2012). Corporate responsibility and compliance with the law: A case study of land, dispossession, and aftermath at Newmont's Ahafo projects in Ghana. Business and Society Review, 117(2), 233-280.

Marfo, E.O., Chen, L., Xuhua, H., Antwi, H.A. \& Yiran, E. (2015) Corporate social responsibility: Driving dynamics on firm's profitability in Ghana. International Journal of Academic Research in Accounting, Finance and Management Sciences, 5(3), 116-132.

Ndzibah, E. (2009). CSR in Ghana? Diversity should not mean dumping. Management of Environmental Quality: An International Journal, 20(3), 271-277.

Nielsen, A.E. \& Thomsen, C. (2012). Corporate social responsibility (CSR) management and marketing communication: Research streams and themes. Hermes-Journal of language and communication in business, $49,49-65$.

Nyuur, R.B, Ofori, D. F. \& Debrah, Y. (2015). The impact of FDI inflow on domestic firms' uptake of CSR activities: The meditating effects of host institutions, Thunderbird International Business Review, 58(2), 147159.

Nyuur, R.B, Ofori, D. F. \& Debrah, Y. (2014). Corporate social responsibility in Sub-Saharan Africa: Hindering and supporting factors. African Journal of Economic and Management Studies, 5(1), 93-113.

Ofori, D. (2010). Executive and management attitudes on social responsibility and ethics in Ghana: Some initial exploratory insights. Global Partnership Management Journal, 1(1/2), 14-24.

Ofori, D. \& Hinson, R. (2007). Corporate social responsibility (CSR) perspectives of leading firms in Ghana. Corporate Governance: The International Journal of Business in Society, 7(2), 178-193.

Ofori, D., Nyuur, R.B. \& Darko, M.D.S. (2014). corporate social responsibility and financial performance: Fact or fiction? A look at Ghanaian banks, Acta Commerci, 14(1), 1-11.

Okoe, A.F. \& Boateng, H. (2016). Assessing the CSR information need of Microfinance Institutions' (MFIs) customers, Journal of Information, Communication and Ethics in Society, 14 (3), 272-287.

Opoku Appiah, K., Asare Amankwah, M. \& Adu Asamoah, L. (2016). Online corporate social responsibility communication: An emerging country perspective, Journal of Communication Management, 20(4), 396-411.

Owusu-Ansah, M. (2013). Corporate social responsibility in Ghana: A comparative analysis and business imperative. International Review of Management and Marketing, 3(4), 184-189.

Puplampu, B.B. \& Dashwood, H.S. (2011). Organizational antecedents of a mining firm's efforts to reinvent its CSR: The case of Golden Star Resources in Ghana. Business and Society Review, 116(4), 467-507.

Schmeltz, L. (2012). Consumer-oriented CSR communication: Focusing on ability or morality?. Corporate Communication: An International Journal, 17(1), 29-49.

Simpson, S.N.A, Aboagye-Otchere, F. \& Lovi, R. (2016). Internal auditing and assurance of corporate social responsibility reports and disclosures: Perspectives of some internal auditors in Ghana, Social Responsibility Journal, 12(40), 706-718

Suchman, M.C. (1995). Managing legitimacy: Strategic and institutional approaches", Academy of Management Review. 20(3), 571-611.

Tench R. \& Amo-Mensah, M. (2018). "The dearth of transmission models of CSR communication", In A. Lindgreen, A. Vanhamme, F. Maon, R. Mardon (Eds.), The use and effectiveness of CSR communications through digital platforms, Routledge, UK.

Tuokuu, F.X.D. \& Amponsah-Tawiah, K (2016). Corporate social Responsibility: Is it and alternative to government? Journal of Global Responsibility, 7 (1), 2041-2568.

Verk, N. \& Golob, U. (2013). Discussion on the approaches to CSR communication research: A literature review, 
Retrieved from: http://www.irdo.si/skupni-cd/cdji/cd-irdo-2013/referati/b-verk-golob.pdf (Accessed 21 January 2018).

Visser, W. (2006). Research on corporate citizenship in Africa: A ten-year review (1995-2005). In: Visser, W., McIntosh, M. and Middleton, C. (eds.) Corporate citizenship in Africa: Lessons from the past, paths to the future (chapter two). Sheffield, UK: Greenleaf publishing.

Visser, W. (2008). CSR in developing economies. In: Crane, A., McWilliams, A., Matten, D. Moon, J. \& Siegel, D. (eds.). The oxford handbook of corporate social responsibility. Oxford: Oxford University Press, 473-449.

Welbeck, E.E. (2017). The influence of institutional environment on corporate social responsibility disclosures in Ghana, Meditari Accountancy Research, 25(2), 216-240.

Yankson, P.W.K. (2010). Gold mining and corporate social responsibility in the Wassa West district, Ghana. Development in Practice, 20 (3), 354-366

Ziek, P. (2009). Making sense of CSR communication. Corporate Social Responsibility \& Environmental Management, 16, 137-145.

Mavis Amo-Mensah is a lecturer at the Department of Communication and Media Studies, University of Education, Winneba, Ghana. She holds Doctor of Philosophy in Public Relations and Communication from Leeds Beckett University, UK. Her research focuses particularly on strategic and corporate communication, corporate social responsibility and sustainability communication. 